\title{
PENGARUH TEAM WORK DAN ORGANIZATION LEARNING TERHADAP KOMITMEN ORGANISASI KEPALA SEKOLAH SMP NEGERI DI KOTA MATARAM
}

\author{
Muhamad Suhardi \\ Program Studi Administrasi Pendidikan, FIPP UNDIKMA \\ Email: -
}

\begin{abstract}
The purpose of this research is to determine the effect of Team Work and Organization Learning on Organization's Commitment in this study middle high school in east Jakarta. The research methodology was survey which were selected by simple random sampling technique. Analysis and interpretation of the data indicate that (1)Team Work has a positive direct effect in Organization's Commitment, (2) Organization Learning has a positivedirect effect in Organization's Commitment, (3) Team Work has a positive direct effect in Organization Learning.
\end{abstract}

Keywords: Team Work, Organization Learning, Organization's Commitment

\section{LATAR BELAKANG}

Kepala sekolah adalah pengelola pendidikan di sekolah secara keseluruhan dan kepala sekolah adalah pemimpin formal pendidikan di sekolahnya. Sebagai pelaksana pengelolaan suatu sekolah proses mengenai komitmen kepala sekolah terhadap organisasi tempatnya bernaung sangat terkait dengan peningkatan kualitas kerjanya. Patut di sadari bahwa kepala sekolah sangat berperan dalam menentukan keberhasilan sekolah. Kedudukan kepala sekolah dalam penyelenggaraan pendidikan di sekolah merupakan figur sentral yang bertanggung jawab terhadap kegiatan pendidikan di sekolah.sumber daya manusia, keuangan dan sarana serta informasi tidak akan dapat berperan optimal dalam pencapaian tujuan sekolah tanpa dikelola baik oleh kepala sekolah.

Komitmen organisasi menjadi hal penting bagi seorang kepala sekolah dalam menciptakan kelangsungan hidup sebuah organisasi. Komitmen organisasi menunjukkan hasrat kepala sekolah untuk terus berjalan dengan baik bagi organisasi sekolah serta untuk tetap tinggal dan bekerja serta mengabdikan diri bagi organisasi sekolah tersebut. Merujuk pada hasil program jabatan kepala sekolah tingkat SMAN dan SMKN di Mataram, pemerintah Kota Mataram berencana akan melakukan program serupa untuk tingkat SDN dan SMPN. (http//www. wartanews.com:2014). Tentunya hal ini dapat berdampak pada kekhawatiran kepala sekolah tingkat SMPN di Jakarta khususnya terhadap program tersebut. Hasil pengamatan selama ini, kepala sekolah tingkat SMPN di Kota Mataram menunjukkan rendahnya komitmen organisasi, seperti rendahnya kesungguhan dalam melaksanakan tugas kepemimpinan dan pembinaan terhadap guru. Berdasarkan permasalahan di atas, penulis ingin mengetahui lebih jelas faktor komitmen 
pemimpin organisasi sekolah yang dapat dipengaruhi oleh teamwork dan organizational learning, melalui penelitian yang berjudul "Pengaruh teamwork dan organization learning terhadap komitmen organisasi kepala sekolah di Sekolah Menengah Pertama Negeri Kota Mataram".

\section{KAJIAN PUSTAKA}

\section{Komitmen Organisasi}

Komitmen

organisasi

didefinisikan sebagai keinginan seorang karyawan untuk tetap menjadi anggota organisasi.Maknanya bahwa seorang karyawan memiliki keinginan terus berkarya pada organisasi tempatnya bekerja. Selain itu Robbins (2009:78) menyatakan bahwa "organizational commitment is defined as a state in which an employee identifies with a particular organization and its goals, and wishes to maintain membership in the organization". Komitmen organisasi adalah suatu keadaan di mana seorang karyawan mengidentifikasi suatu organisasi dan tujuannya, dan dicirikan oleh pengenalan akan tujuan organisasi dan kesediaan tetap menjadi anggota organisasi.

Menurut Newstrom and Davis (2001:49) memberikan definisi komitmen organisasi sebagai berikut, "organizational commitment, or employee loyalty, is the degree to which an employee identifies with the organization and wants to continue actively participating in it. It often reflects the employee's belief in the mission and goals of the firm, willinges to expand effort in their accomplishment, and intention to continue working there".
Komitmen organisasi atau loyalitas karyawan adalah tingkat pengidentifikasian seorang karyawan dengan organisasi dan keinginan untuk secara aktif berpartisipasi di dalamnya. Seringkali mencerminkan kepercayaan karyawan terhadap misi dan tujuan organisasi.Menurut McShane dan Mary (2005:53), "Organizational commitment refers to the employee's emotional attachment to, identification with, and involvement in a particular organization". Komitmen organisasi merupakan pernyataan emosional karyawan untuk dan terlibat dalam sebuah organisasi tertentu.

Menurut Mullins (2005:134) menyatakan bahwa komitmen sebagai, "encapsulating giving all of yourself while at work. This entails such things as using time constructively, attention to detail, making that extra efford, accepting change, co-operation with others, self-development, respecting trust, pride in abilities, seeking improvements and giving loyal support" Pernyataan di atas menerangkan bahwa berkomitmen berarti menyerahkan diri secara total saat berada di tempat kerja, yaitu membutuhkan hal-hal seperti penggunaan waktu secara konstruktif, memperhatikan detail, menumbuhkan usaha ekstra, menerima perubahan, bekerja sama dengan orang lain, pengembangan diri, menghargai kepercayaan, bangga terhadap kemampuan, mencari peningkatan dan memberikan dukungan loyalitas.

Selanjutnya menurut Greenberg and Baron (2005:121), "the concept of organizational commitment is concerned with the degree to which people are 
involved with their organizations and are interested in remaining a part of them". Komitmen organisasi sebagai tingkat pengenalan individu dan keterlibatannya dalam organisasi dan keinginannya untuk tidak meninggalkan organisasi tersebut.Komitmen organisasi seseorang ditunjukkan untuk tetap loyal pada organisasi tempatnya bekerja. Menurut Gibson at all (2006:184)," commitmen to an organization involves three attitudes: 1) sense of identification with the organization"s goals, 2) a feeling of invovement in organizational duties, and 3) a feeling of loyality for the organization". Komitmen terhadap organisasi melibatkan tiga sikap: 1) perasaan memihak terhadap tujuan organisasi, 2) perasaan terlibat dalam tugas-tugas organisasi, 3) perasaan loyal terhadap organisasi. Komitmen seorang kepala sekolah dalam organisasi ditunjukkan dengan kecenderungannya untuk memiliki visi memajukan sekolah, memiliki kativitas untuk kelancaran roda organisasi dan ingin tetap terus berada pada organisasi sekolah.

Berdasarkan uraian di atas dapat disintesiskan bahwa komitmen organisasi adalah keinginan seseorang untuk tinggal pada organisasi atau keterikatan dengan organisasi untuk waktu yang lama dengan indikator:Berpartisipasi aktif, Ingin selalu menetap pada lingkungan organisasi, mempercayai misi dan tujuan organisasi, selalu dapat bekerja pada organisasi, adanya rasa memiliki terhadap organisasi; dan adanya rasa kewajiban untuk tetap menjadi anggota organisasi.

\section{Teamwork}

Menurut Kinicki and Kreitner (2008:232) ; " a team is a small group of people with complementary skills, who work actively together to achieve a common purpose, performance goals and approach for which they hold themselves mutually accountable. Sebuah tim adalah sekelompok kecil orang dengan keterampilan yang saling melengkapi, yang bekerja secara aktif bersama-sama untuk mencapai tujuan yang sama, memiliki tujuan melalui kinerja dan pendekatan yang mereka lakukan dengan saling menahan diri dan akuntabel. Schermerhorn (2011:156) memberikan definisi tentang tim, "as a group of people brought together to use their complementary skills to achievea common purpose for which they are collectively accountable". Tim sebagai sekelompok orang yang secara bersamasama menggunakan keterampilan yang saling melengkapi untuk mencapai tujuan yang sama dan mereka bertanggung jawab secara kolektif.

Menurut Colquitt (2005:372), “ $a$ team consist of two or more people who work interdependently over some time period to accomplish common goals related to some task-oriented purpose". Tim terdiri dari dua orang atau lebihyang bekerja secara bersama selama dalam beberapa periode waktu untuk mencapai tujuan umum yang terkait dengan beberapa tujuan organisasi dan berorientasi pada tugas. George and Jones (2002:325) mendefinisikan, " $a$ team is a formal group in which there is a high level of interaction among group members who work intensely together to achieve a common group goal such as developing a new software package". 
Sebuah tim adalah kelompok formal di manaada interaksi tingkat tinggi antara anggota kelompok yang bekerja intens secara bersama-sama untuk mencapai suatu tujuan umum kelompok seperti mengembangkan paket perangkat lunak baru.

Schermerhorn (2011:156-157) menyatakan bahwa "teamwork occurs when team members accept and live up to their collective accountability by actively working together so that all their respective skills are best used to achieve important goals". Team work terjadi ketika anggota tim menerima dan hidup sampai pertanggungjawaban kolektif mereka dengan aktif bekerja sama sehingga semua keterampilan masingmasing paling baik digunakan untuk mencapai tujuan penting.

Berdasarkan uraian mengenai teori di atas maka dapat disintesiskan yang dimaksud teamwork adalah sebuah sistem pekerjaan yang dikerjakan oleh dua orang atau lebih untuk mengembangkan organisasi dalam rangka mendapatkan tujuan yang direncanakan,terdiri dari beberapa indikator, memahami tujuan dalam pekerjaan, berkontribusi melalui tanggungjawab, antusias terhadap pekerjaan, saling mendukung satu sama lain.

\section{Organization Learning}

Pembelajaran dalam organisasi merupakan suatu proses atau sekelompok proses organisasional yang melibatkan individu, kelompok, level organisasionalyang akan dipengaruhi oleh strategi organisasi. Menurut Krinicki dan Kreitner (2008:414), “ organizational learning is reflective process, played out by members at all levels of the organization, that involves the collection of information from both the external and internal environtments. This information is filtered through a collective sense making process, wich results in shared interpretations that can be used to instigate actions resulting in enduring changes to organization's behavior and theories in use. Pembelajaran organisasi adalah proses reflektif yang dilakukan oleh anggota di semua tingkat organisasi, yang melibatkan sekumpulan informasi dari lingkungan eksternal dan internal. Informasi ini disaring melalui proses kolektif, yang menghasilkan interpretasi bersama sehingga dapat digunakan untuk melakukan tindakan yang mengakibatkan perubahan perilaku organisasi serta teoriteori yang digunakan. (http://www.business)

Berkaitan dengan Organizational Learning, Schermerhorn (2011:416) menyatakan bahwa, "organizational learning is the process of acquiring knowledge and using information to adapt successfully to changing circumstances. For organizations to learn, they must engange in knowledge acquisition, information distribution information interpretation, and organizational retention in adapting successfully to changing circumstances". Pembelajaran organisasi adalah sebuah proses memperoleh pengetahuan dengan menggunakan informasi untuk beradaptasi dengan keadaan yang berubah. Sejalan pendapat di atas, Simon (2007:37) menyatakan bahwa, "three ways in which organizations learn: (1) 
individuals within the organization learn some new fact or procedure, (2) the organization ingests outsiders with knowledge not already in the organization, and (3) the organization incorporates new knowledge into its files and computer systems". Ada tiga cara pembelajaran organisasi: (1) individu dalam organisasi pembelajar melakukan beberapa fakta atau prosedur baru, (2) organisasi memproses pengetahuan yang belum ada dalam organisasi, dan(3) organisasi menggabungkan pengetahuan baru ke dalam data dan sistem komputer.

Danny Miller yang dikutip Kinicki dan Kreitner (2008:417) memberikan ulasan, "the literature on organizational learning and identified six dominant modes of learning: Analytic Learning, Synthetic Learning, Experimental Learning, Interactive Learning, Stuctural Learning, Institutional Learning". Literatur yang berkaitan dengan organizational learning (pembelajaran organisasi) dan diidentifikasikan dalam enam model pembelajaran yang dominan di antaranya adalah pembelajaran analitis, pembelajaran sintesis, pembelajaran eksperimental, pembelajaran interaktif, pembelajaran struktural, dan pembelajaran institusional.

Berdasarkan uraian di atas maka dapat disintesiskan yang dimaksud dengan organizational learning adalah proses pembelajaran yang dilakukan oleh anggota organisasi untuk mau berkembang dalam meningkatkan kinerja untuk kemajuan organisasi. Indikatornya; pengembangan proses pembelajaran, pengembangan kapasitas organisasi, membantu pengembangan komitmen dan tujuan organisasi, mempelajari pelanggan dan lingkungan organisasi Pembelajaran dalam organisasi merupakan suatu proses atau sekolompok proses organisasional yang melibatkan individu, kelompok, level organisasional yang akan dipengaruhi oleh strategi organisasi.

\section{METODE PENELITIAN}

Penelitian ini menggunakan metode survey dengan teknik analisis jalur (path analys) Data penelitian ini dikumpulkan dengan cara memilih sampel dalam populasi. Populasi dalam penelitian ini seluruh Kepala Sekolah SMP Negeri di Kota Mataram yang berjumlah 24 Kepala Sekolah. Pengumpulan data digunakan untuk penelitian ini adalah statistika deskriptif dan statistika inferensial.

\section{HASIL PENELITIAN DAN PEMBAHASAN}

\section{Pengaruh Teamwork terhadap Komitmen Organisasi}

Teamwork atau kerja sama tim merupakan bentuk kerja kelompok dengan keterampilan yang saling melengkapi serta berkomitmen untuk mencapai target yang sudah disepakati sebelumnya untuk mencapai tujuan bersama secara efektif dan efisien. Harus disadari bahwa teamwork merupakan peleburan berbagai pribadi yang menjadi satu pribadi untuk mencapai tujuan bersama. Tujuan tersebut bukanlah tujuan pribadi, bukan tujuan ketua tim, bukan pula tujuan dari pribadi yang paling populer di tim.

Sebagaimana yang disampaikan Schermerhorn (2011:156-157) 
menyatakan bahwa, " teamwork occurs when team members accept and live up to their collective accountability by actively working together so that all their respective skills are best used to achieve important goals". Team work terjadi ketika anggota tim menerima dan hidup sampai pertanggung jawaban kolektif mereka dengan aktif bekerja sama sehingga semua keterampilan masingmasing paling baik digunakan untuk mencapai tujuan penting.

Hal tersebut sejalan yang disampaikan Greenberg and Baron, "the concept of organizational commitment is concerned with the degree to which people are involved with their organizations and are interested in remaining a part of them". Komitmen organisasi sebagai tingkat pengenalan individu dan keterlibatannya dalam organisasi dan keinginannya untuk tidak meninggalkan organisasi tersebut..

Berdasarkan uraian tersebut maka teamwork yang baik menyebabkan pengaruh yang tinggi terhadap komitmen organisasi.Maka dapat disimpulkan diduga terdapat pengaruh langsung positip teamwork terhadap komitmen organisasi.

\section{Pengaruh Organizational Learning terhadap Komitmen Organisasi}

Organizational Learning atau pembelajaran organisasi merupakan suatu proses atau sekelompok proses organisasional yang melibatkan individu, kelompok, level organisasional yang akan dipengaruhi oleh strategi organisasi. Sejalan pendapat di atas, Simon menyatakan bahwa, "three ways in which organizations learn: (1) individuals within the organization learn some new fact or procedure, (2) the organization ingests outsiders with knowledge not already in the organization, and (3) the organization incorporates new knowledge into its files and computer systems". Ada tiga cara pembelajaran organisasi: (1) individu dalam organisasi pembelajar melakukan beberapa fakta atau prosedur baru, (2) organisasi memproses pengetahuan yang belum ada dalam organisasi, dan(3) organisasi menggabungkan pengetahuan baru ke dalam data dan sistem komputer.

McShane dan Mary, "organizational commitment refers to the employee's emotional attachment to, identification with, and involvement in a particular organization" Komitmen organisasi merupakan pernyataan emosional karyawan untuk dan terlibat dalam sebuah organisasi tertentu.

Berdasarkan penjelasan di atas maka Organizational Learning atau pembelajaran organisasi yang yang baik menyebabkan pengaruh terhadap komitmen organisasi. Maka diduga terdapat pengaruh langsung positip Organizational Learning terhadap komitmen organisasi.

\section{Pengaruh Teamwork terhadap Organizational Learning}

Teamwork merupakan sarana yang sangat baik dalam menggabungkan berbagai talenta dan dapat memberikan solusi inovatif suatu pendekatan yang mapan, selain itu ketrampilan dan pengetahuan yang beranekaragam yang dimiliki oleh anggota kelompok juga merupakan nilai tambah yang membuat teamwork lebih menguntungkan jika 
dibandingkan seorang individu yang brilian sekalipun. Teamwork merupakan kumpulan individu yang bekerjasama untuk mencapai suatu tujuan. Kumpulan individu-individu tersebut memiliki aturan dan mekanisme kerja yang jelas serta saling tergantung antara satu dengan yang lain.

Berkaitan pendapat di atas Newstrom menyatakan, "individual employees perform operating tasks, but the vast majority of them work in regular small groups where their efforts must fit together like the pieces of a picture puzzle. Where their work is interdependent, they act as a task team and seek to develop a cooperative state called teamwork". Individu setiap anggota organisasi dalam menunjukkan pekerjaan melalui kegiatan, namun sebagian besar dari mereka bekerja dalam kelompok kecil di mana pekerjaan yang mereka lakukan harus cocok sama seperti puzle. Pekerjaan mereka saling bergantung, dan mereka bertindak sebagai tim dan berusaha untuk mengembangkan organisasi yang disebut dengan teamwork.

Menurut Angelo Kinicki dan Robert Kreitner, "teamwork occurs when team members accept and live up to their collective accountability by actively working together so that all their respective skills are best used to achieve important goals". Teamwork terjadi ketika anggota tim menerima dan hidup sampai pertanggung jawaban kolektif mereka dengan aktif bekerja sama sehingga semua keterampilan masingmasing paling baik digunakanuntuk mencapai tujuan penting Teamwork yang baik pada personil organisasi dapat menunjang cara personil dalam melakukan pembelajaran organisasi atau organizational learning. Seperti diketahui bahwa organizational learning merupakan jenis aktivitas dalam Organisasi.Organizational learning yang baik pada suatu organisasi yang anggotanya belajar secara terus menerus dapat meningkatkan kemampuan demi tercapai tujuan organisasi.

Berdasarkan uraian tersebut maka teamwork yang baik menyebabkan pengaruh terhadap organizational learning.Maka diduga terdapat pengaruh langsung positip teamwork terhadap organizational learning.

\section{KESIMPULAN}

Berdasarkan hasil perhitungan penelitian dan hasil analisis data yang telah di uraikan di Bab IV, maka dapat diperoleh beberapa kesimpulan sebagai berikut, (1) Team work berpengaruh langsung positip terhadap Komitmen Organisasi. Artinya peningkatan soliditas Team work mengakibatkan peningkatan Komitmen Organisasi Kepala Sekolah SMPN Kota Mataram. (2) Organizational Learning berpengaruh langsung positip terhadap Komitmen Organisasi. Artinya peningkatan Organizational Learning mengakibatkan peningkatan Komitmen Organisasi Kepala Sekolah SMPN Kota Mataram. (3) Team work berpengaruh langsung positip terhadap Organizational Learning. Artinya peningkatan soliditas Team work mengakibatkan peningkatan Organizational Learning.

\section{DAFTAR PUSTAKA}

Colquitt, Jasson A. Jeffery A. Lepine, Michael J. Wesson, Organizational 
Behavior ( New York:McGraw Hill Learning, Annals of Information Systems International Edition, 2009)

4, DOI 10.1007/978-1-4419-0011-1_1, (C) Danim, Sudarwan. Motivasi Springer Science+Business Media, LLC Kepemimpinan dan Efektivitas 2009

Kelompok. (Jakarta:PT Rineka Cipta Kinicki, Angelo and Robert Kreitner, Utama,2004) Organizational Behavior, key concept, Davis, Keith and John W. Newstrom, skills \& best practice, (New York:Mc Human Behavior at Work,Organizational Graw Hill, 2008)

Behavior, (New York:McGraw Hill, Luthans, Fred.Organizational Behavior, 1989) 7th ed, (New York : McGraw-Hill,2006)

George, Jennifer M. and Gareth R. Jones, McShane, Steven L. and Mary Ann Von Organizational Behavior, third edition, Glinow.Organizations Behavior: (New Jersey:Prentice Hall, 2002) Emerging Realities for the workplace Gibson et al, Revolution (New York: Mc Graw Hill, Organization:Behavior,structur,processe 2005)

$s$ (New York.Mc Graw Hill.2006) Mullins, Laurie J.Management and Greenberg, Jerald dan Robert A. Organizational Behavior.Seventh Baron.Behavior in Organization. $8^{\text {th }}$ edition.(Ediburgh Gate edition,(New Jersey : Prentice Hall, Harlow:Prentice Hall, 2005) 2005)

King, W.R. (ed.), Knowledge Quick, Understanding Organizational Management and Organizational Behavior, (Ohio : South-Western, 2005) 